\title{
Eco-Efficiency Applied to Dairy Processing: From Concept to Assessment
}

\author{
Scott Benoit \\ STELA Dairy Research Center, Institute of Nutrition and Functional Foods \\ Department of Food Science, Université Laval, Québec G1V 0A6, QC, Canada \\ E-mail: Scott.Benoit.1@ulaval.ca
}

Manuele Margni

CIRAIG, Polytechnique Montréal, Department of Mathematical and Industrial Engineering Montréal H3C 3A7, QC, Canada

E-mail: Manuele.Margni@polymtl.ca

\begin{abstract}
Christian Bouchard
Department of Civil Engineering and Water Engineering, Université Laval Québec G1V 0A6, QC, Canada

E-mail: Christian.Bouchard@gci.ulaval.ca
\end{abstract}

Yves Pouliot (Corresponding author)

STELA Dairy Research Center, Institute of Nutrition and Functional Foods Department of Food Science, Université Laval, Québec G1V 0A6, QC, Canada

Tel: 1-418-656-5988Ｅ-mail: Yves.Pouliot@fsaa.ulaval.ca

Received: September 12, 2018 Accepted: September 28, 2018 Published: December 7, 2018 doi:10.5296/emsd.v8i1.13607

URL: https://doi.org/10.5296/emsd.v8i1.13607

\section{Abstract}

Eco-efficiency is a concept which aims at decoupling economic growth from resource use 
and pollution. The objective of this paper is to review how the application of this concept to dairy processing has evolved over time. Following the introduction of the concept, guidelines and recommendations were introduced in the dairy sector. The absence of a lifecycle perspective and means of measuring improvement led to a subsequent addition of efficiency and intensity assessments. As restrictive regulations and comprehensive methodologies integrating the life-cycle perspective in eco-efficiency assessments were virtually non-existent, the ISO 14045 standard was developed. However, as of yet the dairy processing sector does not appear to have embraced the ISO methodology. Nonetheless, process simulation tools may help and could therefore contribute to the implementation of the eco-efficiency assessments in the dairy processing sector.

Keywords: Eco-efficiency, Dairy processing, Historical overview, Life-cycle analysis, Process simulation

\section{Introduction}

Eco-efficiency is a concept that emerged in the early nineties as a form of management philosophy devised for the world of business and industry, and that adheres to a sustainable development approach. With a view to decoupling economic growth from resource use and pollution, the concept encourages businesses to search for economic benefits that yield parallel environmental impact reductions (WBCSD, 2005). The eco-efficiency concept offers several distinctive features that differentiate it from related concepts that emerged in recent decades. Firstly, in contrast with Green Growth which is applicable on the scale of a region or a country (UNESCAP, 2009), eco-efficiency is an enterprise-wide framework. Furthermore, it links business profitability to resource productivity, while the Cleaner Production concept focuses solely on the environmental aspect (UNEP-WBCSD, 1998). Finally, it emphasises value creation, aiming to route competitiveness and taking into account sustainable consumption as well as sustainable production (DeSimone \& Popoff, 1997).

Milk is one of the top agricultural commodities in terms of both quantity and value - with a total production of 770 billion litres valued at USD 328 billion, milk ranked third by production tonnage and was the top agricultural commodity in value terms on a global scale in 2013 (FAO, 2016). Dairy manufacturers are responsible for the processing of milk into dairy products. At global level, skimmed milk (75\%), cheese (12\%) and butter (3\%) represent over $90 \%$ of all processed milk (FAO, 2016). Although dairy processing activities add value to raw milk and create jobs (about 240 million people are directly or indirectly employed in this sector worldwide), dairy products also involve significant use of resources and generation of polluting discharges (De Jong, 2013).

While there appears to be reasonable grounds for profitable but resource-intensive industries to embrace the eco-efficiency concept, twenty-five years later, it is far from being fully implemented in the dairy processing sector. The main objective of this paper is to provide a historical perspective of the eco-efficiency concept and describe how its application to dairy processing has evolved over time in the dairy processing industry. 


\section{The Eco-efficiency Concept upon its Creation}

\subsection{Origins of the Concept}

The term eco-efficiency originates from an internal contest organised at the Business Council for Sustainable Development (BCSD) in the early nineties, during the preparation of the first United Nations Conference on Environment and Development (UNCED). The purpose of that contest was to sum up, with as few words as possible, the business end of sustainable development (WBCSD, 2000a). The first UNCED, also known as the 1992 Earth Summit, was based on the groundwork carried out by the United Nations World Commission on Environment and Development (UNWCED) brought together in a report entitled Our Common Future, published in 1987. Also referred to as the Brundtland Report, this document introduced for the first time the concept of sustainable development: a development that "meets the needs of the present without compromising the ability of future generations to meet their own needs » (UNWCED, 1987). The BCSD was established in preparation for the 1992 event, with the aim of exploring the possible interrelationships between business imperatives and sustainable development. The results of the BCSD's work were first compiled into a book entitled Changing Course: A Global Business Perspective on Development and the Environment, published in 1992, then presented at the Earth Summit. Changing Course focuses on how enterprises can combine economic growth with environmental protection and explains the entrepreneurial concept of eco-efficiency (BCSD, 1992). Eco-efficiency is therefore a concept developed by a business council for the attention of the business community: the 1992 Earth Summit posed the challenge of sustainable development, and eco-efficiency was presented by the BCSD as its business answer.

\subsection{Presentation of the Concept}

From its creation in 1992, the eco-efficiency concept was used to describe activities that create economic value while continuously reducing their environmental impact (DeSimone \& Popoff, 1997). The underlying idea is to decouple economic activities from pollutant releases and resource uses (OECD, 1998). With its prefix «eco-» referring to both economics and ecology (BCSD, 1993) it lies at the interface between two dimensions of sustainable development, being both ecologically bearable and economically viable. The social dimension of development, although essential to the success of sustainable development (Gendron \& Gagnon, 2011), is not taken into account in the eco-efficiency concept. Efficiency is a measurable concept used to determine which of several systems is the most efficient in performing the same task (Oxford English Dictionary, 2012). System efficiency is usually quantified by calculating the ratio of the useful output to the total input - the most efficient system thus being the one with the highest efficiency ratio. Basically, eco-efficiency can be merely viewed as a concept of resource productivity: creating more value with less impact (WBCSD, 2000a). Nonetheless, it encompasses several key aspects as highlighted in the official definition of eco-efficiency.

\subsection{Eco-efficiency Key Aspects According to the BCSD}

As a result of work done between 1993 and 1997 at the workshops organised by the BCSD, 
an official definition of eco-efficiency was drawn up: "Eco-efficiency is reached by the delivery of competitively-priced goods and services that satisfy human needs and bring quality of life, while progressively reducing environmental impacts and resource intensity throughout the life cycle, to a level at least in line with the earth's estimated carrying capacity» (BCSD, 1993). As suggested by the BCSD, this definition can be broken down into five key aspects (BCSD, 1993).

Firstly, the definition recommends businesses to place the main focus on what they have to offer: products and / or services rather than on the expected returns. The second key aspect of the definition is the focus on human needs and quality of life. The idea is that, when eco-efficiency improvement is at stake, customers' needs and quality of life must be thoroughly considered at both the design and the supply stage of goods. From a certain point of view, such considerations enable production and delivery of more satisfying goods, which allow for greater associated values. The third aspect is the life-cycle perspective. Each of the life-cycle stages of the products must therefore be taken into consideration: from extraction and acquisition of raw materials, through energy and material production and manufacturing, to use and end of life treatment and final disposal (ISO, 2006a). Still according to the BCSD, the fourth key aspect of the eco-efficiency concept is the recognition of the Earth's carrying capacity (BCSD, 1993). This aspect unequivocally ranks alongside the environmental dimension of sustainable development: an ecologically bearable development — which does not jeopardise the ability of future generations to meet their own needs. The final key aspect of the definition is that eco-efficiency is not an end in itself. It is a concept, a framework of development, designed to route the competitiveness of companies. To this end, criteria and operational guidelines were established before actual eco-efficiency assessment methodologies were adopted.

\section{WBCSD Eco-efficiency Guidelines}

Upon merging with the World Industry Council for the Environment (WICE), the BCSD became the World Business Council for Sustainable Development (WBCSD) in 1995. The WBSCD (DeSimone \& Popoff, 1997) formulated seven guidelines for eco-efficiency improvements prior to the advent of eco-efficiency measurements. In line with the key aspects of the concept, these guidelines were to be implemented by companies wishing to do so when working on new or redesigned products, processes, or services.

The first three recommendations aim at reducing resource extraction and polluting emissions:

1) Reduction of the material intensity of goods and services.

2) Reduction of the energy intensity of goods and services.

In the absence of environmental impact analysis, it was assumed that reducing material consumption and energy requirements (1) \& (2) would lead to less extraction work, fewer polluting emissions and wastes, and thus reduced environmental impacts throughout the whole life-cycle. From a dairy processing point of view, these could translate into limitations of material and energy losses. The introduction of processes offering higher production yields, processing equipment with improved energy efficiencies, or simply more efficient 
technologies (such as the tower-less powder process recently developed by Schuck et al. (2016)), could allow for successful implementations of these guidelines.

3) Reduction of toxic compounds dispersions.

Toxic compound dispersions (3) at all life-cycle stages must be reduced in order to restrict their potential effects on environment and human health. From an operational perspective, toxic emissions to air and water must be prevented. If their generation cannot be avoided, treatment systems should be put in place to deal with the harmful substances in responsible ways. The last four guidelines of the WBCSD were designed to promote sustainable solutions:

4) Enhancement of material recyclability.

5) Maximisation of sustainable use of renewable resources.

6) Extension of product durability.

7) Increase in service intensity of goods and services.

The seventh recommendation is the only one related to an increase in the value associated with the product or service. Even if all of the guidelines can contribute to a value increase, the vast majority are directly geared towards the potential reduction of environmental impacts. In all logic, implementing recommendations that have a potential to reduce environmental impacts (and even possibly increasing value) could lead to more eco-efficient products and services. In the absence of quantitative assessment of the likely effects these modifications would have, results seem however relatively uncertain.

Another interpretation model of these guidelines was later suggested (WBCSD, 2005). It presents four areas of opportunity for eco-efficiency improvement and identifies the potential actors: suppliers to re-design processing equipment, engineers to re-engineer manufacturing processes, product development teams to (re-)valorise by-products, and marketers to re-think the customer-product (or customer-service) relationship. The main idea remains the same: efforts must be taken to ensure higher yields and efficiencies at production stages, and products should be re-visited to optimise their associated value - application of eco-efficiency principles thus creating increased value for customers through the sustainable use of resources. Once again, however, effects on eco-efficiency can be very difficult to appraise without careful quantitative assessments. Nevertheless, by adding such guidelines to the eco-efficiency concept the WBCSD appears to have encouraged its adoption and promotion by many recognised organisations and business communities. With the evolution of eco-efficiency from concept to applicable guidelines, evidence of growing interests emerged, and since the end of the 1990s eco-efficiency has been promoted among dairy processors (Wardrop Engineering, 1997; UNEP-DEPA, 2000; NRCOEE, 2001; UNEP, 2004). However, it is important to take into consideration the life-cycle perspective of the dairy processing activity as it is an integral dimension of the eco-efficiency concept. 


\section{The Dairy Processing Activity from a Life-cycle Perspective}

Dairy processing is the central stage in the life-cycle of dairy products. This manufacturing activity consists in the transformation of raw materials (of which raw milk is the most significant) into dairy consumer products with specific qualities in terms of nutritional value, organoleptic profile (texture, taste, flavour, and visual aspect), and shelf life. Not only it is a multi-stakeholder activity, but it is also a consumer of natural resources and a source of potentially polluting discharges.

\subsection{A multi-stakeholder Activity}

The life cycle perspective, imposed by the eco-efficiency concept, allows for identification of all the stakeholders involved either directly or indirectly in the dairy processing activity. While the dairy processor is a key actor in the dairy product life-cycle, processing is only one of the life-cycle stages of dairy products, and other stakeholders are involved in the upstream and downstream stages. Similarly, multiple material and energy flows are used and consumed in dairy processing facilities. Additional stakeholders therefore participate in the other life-cycle stages of these flows. Figure 1 presents the range of stakeholders involved in the dairy processing activity. It also shows, for each stakeholder, the life-cycle stages of the main material and energy flows used and consumed at the manufacturing stage of dairy products. Milk production itself involves numerous stakeholders. Dairy cattle must indeed be nurtured and milked daily, animal feeds need to be produced and distributed, manure must be handled in responsible ways, juveniles, reproduction, and culled animals have to be taken care of, and raw milk must be handled in a sanitary manner until collected by the milk hauliers. Dairy processing is the manufacturing stage of dairy products, but it is also the consumption stage of many material and energy flows. For instance, it uses processing equipment that must be produced and transported by other stakeholders, and it consumes electricity and natural gas which are produced and distributed by different actors. As for all the actors involved, the facility in which the activity takes place must be built and maintained. Materials such as concrete and steel reach their consumption phase in this endeavour. These materials need to be produced and transported prior to being used for construction and maintenance, which involves many additional actors. Like all the other stakeholders, the dairy processor is also a source of wastes and discharges that must be collected and treated by several additional actors in order to avoid polluting emissions. Indeed, various types of wastes and discharges are collected at the dairy processing facility. While part of production wastes (such as waste waters) may be treated on site, the remaining part is collected and treated by specific waste processors. Furthermore, at the end of their useful life, used consumables must be specifically addressed in order to maximise re-use and recycling of materials and minimise the potential negative impacts of these discards. Depending on their nature, ultimate losses (wastes that cannot be valued) are either landfilled, burned, or diluted in the environment. The ultimate stakeholders involved in the dairy processing activity are the distributors and consumers with actors directly or indirectly involved in product storage and conservation, packaging and out-of-date product end-of-life treatments. 

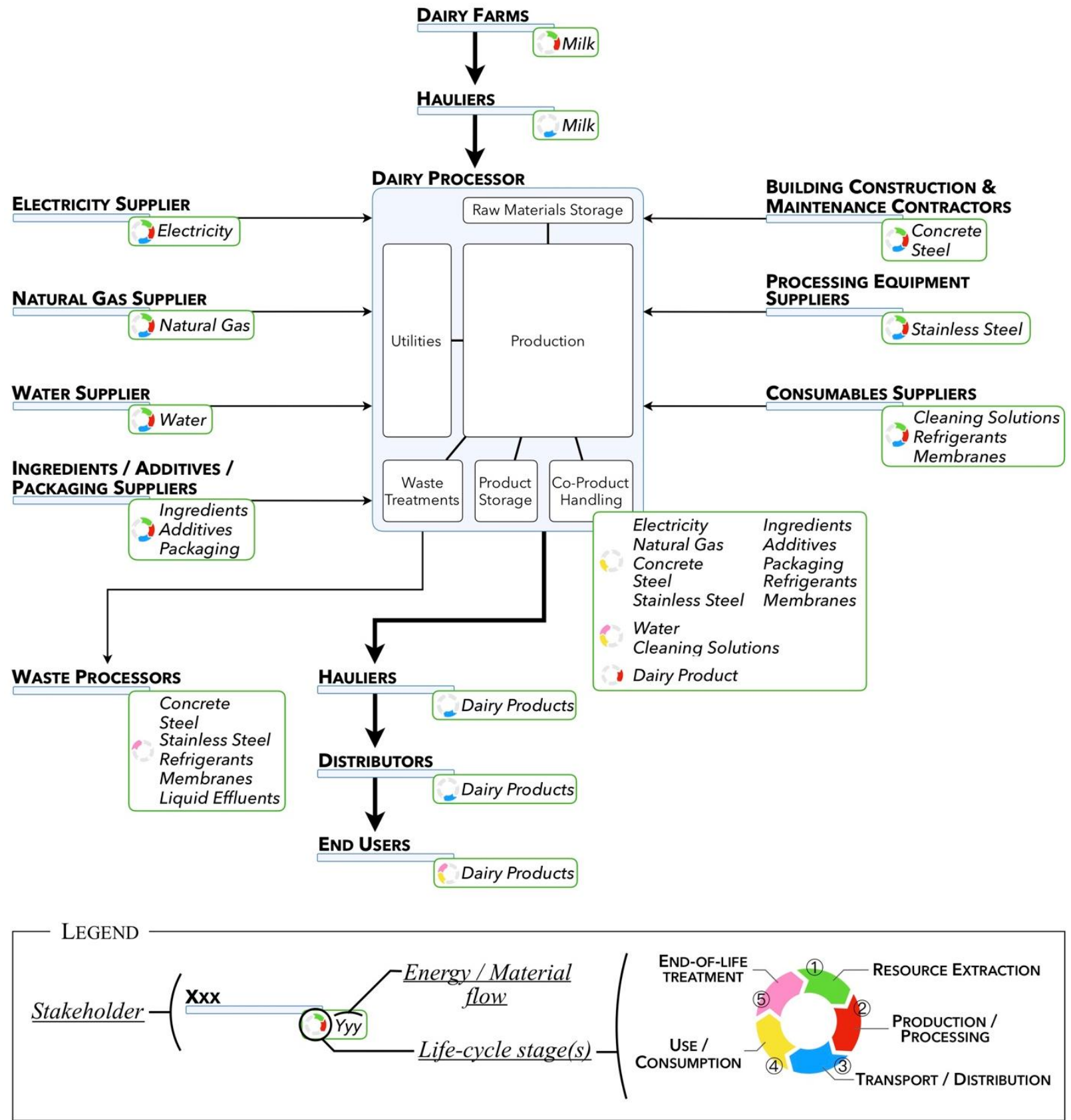

Figure 1. Schematic representation of the range of stakeholders involved in the dairy processing activity. Presentation of the main materials and energy flows, and indications of the related life-cycle stages

4.2 A Consumer of Natural Resources and a Source of Potential Pollution Released into the Environment

Throughout their whole life-cycle, dairy products rely on natural resources such as land, water, and energy. Although the environmental impacts of dairy products may significantly vary depending on the product considered and its associated regional context, they should not be overlooked. 


\section{Mll Macrothink}

Raw milk is obviously the main material consumed by the dairy processing activity. As presented in figure 2, the amount of raw milk required is different in each category of processed dairy products. Depending on the end-product, production of one kilogram of dairy product requires from 1.1 to $20.3 \mathrm{~kg}$ of raw milk and generates from 0.1 to $19.3 \mathrm{~kg}$ of co-products. Contrary to ultimate losses, co-products are not wasted, and in one way or another, they can be valued (De Boer, 2014).

\begin{tabular}{|c|c|c|c|c|c|}
\hline \multirow{2}{*}{ Dairy Product } & \multicolumn{4}{|c|}{ Composition \% (w/w) } & \multirow{2}{*}{ Mass of raw milk required and co-product generated per kilogram of dairy product. } \\
\hline & $P$ & $F$ & $M$ & Source & \\
\hline Skim Milk & 3.4 & 0.1 & 90.8 & $A$ & $\begin{array}{l}1.1 \mathrm{~kg} \text { - Raw Milk } \\
1 \mathrm{~kg} \mid 0.1 \mathrm{~kg}-\text { Cream (40\% fat) }\end{array}$ \\
\hline Cheddar & 25.0 & 33.0 & 37.0 & $B$ & \begin{tabular}{|l|l|}
$7.9 \mathrm{~kg}$ - Raw Milk \\
$1 \mathrm{~kg}$ & $6.9 \mathrm{~kg}$ - Sweet Whey \\
\end{tabular} \\
\hline Ice Cream & 3.0 & 10.0 & 63.5 & $C$ & \begin{tabular}{|l|l|}
$2.5 \mathrm{~kg}-$ Raw Milk \\
$1 \mathrm{~kg}$ & $1.5 \mathrm{~kg}$-Skim Milk \\
\end{tabular} \\
\hline Greek Style Yogurt & 10.2 & 0.4 & 85.1 & $D$ & 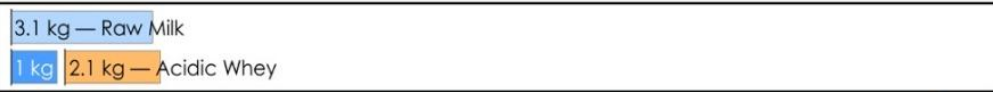 \\
\hline Butter & 1.0 & 81.0 & 16.0 & $B$ & \begin{tabular}{|l|l|}
$20.3 \mathrm{~kg}$ - Raw Milk \\
$1 \mathrm{~kg}$ & $19.3 \mathrm{~kg}$ - Skim Milk \\
\end{tabular} \\
\hline Whole Milk Powder & 25.8 & 27.3 & 3.3 & $B$ & \begin{tabular}{|l}
$7.6 \mathrm{~kg}$ - Raw Milk \\
$1 \mathrm{~kg}$ \\
$6.6 \mathrm{~kg}$ - Water \\
\end{tabular} \\
\hline
\end{tabular}

Figure 2. Mass of raw milk required, and co-product generated, per kilogram of dairy product. Calculations based on composition data. Milk losses are not accounted for.

$\boldsymbol{P}$ : Proteins, $\boldsymbol{F}$ : Fat, $\boldsymbol{M}$ : Moisture

Raw milk composition (w/w): $3.3 \%$ proteins, $4.0 \%$ fat, $87.2 \%$ moisture (Walstra et al., 2006).

Sources: A: Walstra et al., 2006; B: CDC, 2017; C: Tetra Pak, 2015; D: USDA, 2016.

Milk production uses an important amount of natural resources: following beef, milk is the most resource-intensive source of calories (World Resources Institute, 2016). On a global scale, feeding dairy animals mobilises 1 billion ha of land, which represents nearly $7 \%$ of earth's land surface (FAO, 2016). 84\% of this land area is used primarily as pastures and rangelands. The remaining $16 \%$ mobilises $10 \%$ of the planet's arable land and is used to produce the dairy herd feed intake (FAOSTAT, 2014; FAO, 2016).

Feed material production consumes significant amounts of resources and can be associated with land degradation, water pollution, losses of biodiversity or deforestation (FAO, 2016). Dairy farming is indeed associated with both the potential use of chemical fertilisers and pesticides in fodder production, and the generation of manure and slurries, which may pollute surface water and groundwater (UNEP-DEPA, 2000).

A review-work completed by the International Dairy Federation stressed that the milk production stage is responsible for most of the environmental impacts of dairy products (IDF, 2009). In the life-cycle of fluid milk, dairy farms contribute to more than $80 \%$ of greenhouse gas emissions (GHG) (IDF, 2009) — which total about 1 kilogram $(\mathrm{kg})$ of $\mathrm{CO}_{2}$ equivalent per $\mathrm{kg}$ of product, about two and ten times the GHG emissions associated with egg and wheat production, respectively, for the same calorie intake (World Resources Institute, 2016). For cheese, contribution of milk production to GHG emissions increases to more than $90 \%$ - for 
a total close to $9 \mathrm{~kg}$ of $\mathrm{CO}_{2}$ equivalent per $\mathrm{kg}$ of product (IDF, 2009; Thoma et al., 2013). Together, GHG emissions from dairy animals add up to 3.1 gigatons of $\mathrm{CO} 2$ equivalent per year, which represents more than $6 \%$ of 2016 total GHG emissions and twice as much as international transport that same year (FAO, 2016; Olivier et al., 2017).

Milk production is not only the main GHG emitter in dairy products life-cycles, it is also accountable for the majority of non-renewable energy consumption. In fluid milk or cheese life-cycles, the milk production stage contributes to $38 \%$ and $72 \%$, respectively, of the non-renewable primary energy use (IDF, 2009). About $60 \%$ of that energy is used for the feed production. The remaining $40 \%$ corresponds primarily to the electricity used on farm and the fuel consumed for truck and tractor operations (IDF, 2009).

Furthermore, milk production requires large volumes of fresh water since 20 to 140 litres per kilogram of raw milk produced are consumed at the dairy farming stage (Quantis \& Groupe Agéco, 2011). While this amount is one of the lowest for animal-based foods (when comparing on a calorie intake basis), it represents two to three times the volumes required by plant-based foods to provide the same number of calories (World Resources Institute, 2016).

The dairy processing stage is the second-largest contributor to the dairy product environmental impacts. It consumes resources through its water and energy usage and can be responsible for significant discharges of organic matters in the effluent streams (UNEP-DEPA, 2000).

In terms of global warming potential, dairy processing (excluding packaging materials) contributes to $4 \%$ of fluid milk and cheese impacts. With regards to non-renewable primary energy use, these contributions increase to $38 \%$ and 10\%, respectively (IDF, 2009), which corresponds to the consumption of various forms of energy at the dairy processing stage (De Jong, 2013).

According to Wang (2008), the five main operations performed at dairy processors (heating, cooling, concentration, drying, and cleaning) account for at least $50 \%$ of energy consumption in dairy processing. These add up to $96 \%$ of energy consumption in the case of milk powder production (Wang, 2008). Different sources of energy are used in dairy plants. The major ones are electricity, natural gas, and other fuels such as heavy fuel oil, light fuel oil, and propane (NRCOEE, 2001; Wardrop Engineering, 1997). Each of these sources inevitably produces different environmental impacts, whether at the extraction and production stage, or at the consumption stage. As pointed out by the Australian Industry Group (AIG, 2010), it is clear that the most energy intensive activities involve heat generation - such activities include thermisation, pasteurisation, thermal concentration, and drying - which explains why dried products are associated with higher fuel consumptions.

Dairy processors are also high consumers of fresh water. Although it varies considerably depending on plant size and type of processing, fresh water consumption at the processing stage typically ranges from 1.3 to 2.5 litres of fresh water per kilogram of raw milk processed (UNEP-DEPA, 2000). About $60 \%$ is used as cooling water or for steam generation (Wardrop Engineering, 1997) while the remaining $40 \%$ is consumed primarily during cleaning and 
disinfection operations. Most water consumed during processing ultimately becomes effluent.

In addition to water, dairy processing effluents contain detergents, as well as acidic and caustic cleaning agents, but it is the milk components which are the most challenging. Milk losses to the effluent streams can actually range from 0.5 to $2.5 \%$ of the incoming milk, and their high organic load due to the presence of milk components make them pollute more than typical waste-waters (UNEP-DEPA, 2000).

\subsection{Implementation of the Eco-efficiency Concept in Dairy Processing}

From 1995 onwards, the WBCSD conducted eco-efficiency workshops in many parts of the world, while several United Nations (UN) agencies, the Organisation for Economic Co-operation and Development (OECD), the European Commission, and many national governments started promoting awareness of eco-efficiency: UNEP-DEPA (2000), UNEP (2004), UNCTAD (2004), UNESCAP (2009), OECD (1998, 2000), and NRTEE (2001).

Table 1 reports the list of recommended actions for eco-efficiency improvements in dairy processing according to the main guides and manuals specifically encouraging dairy processors to adopt measures promoting eco-efficiency and sustainability improvements.

The recommended actions can be divided into four fields: water, energy, raw materials, and waste related recommendations, and the vast majority are related to potential reductions of environmental impacts. If the links between the recommendations and the WBCSD's eco-efficiency guidelines on material and energy intensities and polluting emissions $(1,2, \&$ 3 ) are fairly obvious and direct, the links to the WBCSD's guidelines related to durability and service $(6 \& 7)$ are less evident and in most cases indirect. Implementation of these recommendations could have significant effects on the environmental impacts associated with the dairy processing stage of the dairy products life-cycles - effects on water footprint, non-renewable energy use, and greenhouse gas emissions, to name but a few. However, the life-cycle perspective implied by the eco-efficiency concept does not feature in the recommendations reviewed here. They focus on actions to be taken at the dairy processors while actions for eco-efficiency improvements should encompass a system boundary beyond the sole company's activities. In strict logic, upstream and downstream activities should be involved when undertaking eco-efficiency improvements. In accordance with the proverbial management adage that you can't manage what you don't measure, the OECD encouraged the use of Life-Cycle Analysis (LCA) to assess environmental impacts since 1998 (OECD, 1998). Based on similar considerations, the UNEP and the NRTEE concurrently recommended that guidelines implementation be supplemented by assessments and measurements in order to concretely monitor intensity and eco-efficiency improvements (UNEP, 2004; NRTEE, 2001). 
Table 1. Recommended actions for eco-efficiency improvements in dairy processing according to the main dedicated guides and manuals

\begin{tabular}{|c|c|c|c|c|c|c|c|c|c|c|c|c|c|c|c|c|c|c|}
\hline & & \multicolumn{10}{|c|}{ Manual or guide } & \multirow{2}{*}{\multicolumn{7}{|c|}{ Related WBSCD's guidelines }} \\
\hline Field & Recommended action & A & $\mathrm{B}$ & $\mathrm{C}$ & $\mathrm{D}$ & $\mathrm{E}$ & $\mathrm{F}$ & $\mathrm{G}$ & $\mathrm{H}$ & $\mathrm{I}$ & $\mathrm{J}$ & & & & & & & \\
\hline \multirow{7}{*}{ Water } & $\begin{array}{l}\text { Use continuous processing rather than batch } \\
\text { processing to reduce cleaning frequency. }\end{array}$ & - & $\bullet$ & - & - & - & - & - & - & - & - & (1) & (2) & (3) & - & - & (6) & (7) \\
\hline & $\begin{array}{l}\text { Improve equipment maintenance to avoid } \\
\text { water leakage. }\end{array}$ & $\bullet$ & $\bullet$ & $\bullet$ & - & $\bullet$ & - & - & - & $\bullet$ & - & (1) & (2) & - & - & - & (6) & - \\
\hline & $\begin{array}{l}\text { Implement automated Cleaning-In-Place (CIP) } \\
\text { systems for water use optimisation. }\end{array}$ & $\bullet$ & $\bullet$ & $\bullet$ & - & $\bullet$ & - & - & - & $\bullet$ & $\bullet$ & (1) & (2) & (3) & - & - & - & - \\
\hline & $\begin{array}{l}\text { Perform cleaning tasks using high pressure and } \\
\text { low volume to reduce water consumption. }\end{array}$ & $\bullet$ & $\bullet$ & $\bullet$ & - & $\bullet$ & - & - & - & $\bullet$ & - & (1) & - & - & - & (5) & - & (7) \\
\hline & $\begin{array}{l}\text { Reuse relatively clean waste-waters for } \\
\text { non-critical applications. }\end{array}$ & - & $\bullet$ & $\bullet$ & - & $\bullet$ & - & - & - & - & $\bullet$ & (1) & - & - & (4) & (5) & $(6)$ & (7) \\
\hline & Recover condensates. & - & - & $\bullet$ & - & $\bullet$ & - & - & - & - & $\bullet$ & (1) & - & - & (4) & (5) & $(6)$ & $(7)$ \\
\hline & $\begin{array}{l}\text { Install membrane systems to improve water } \\
\text { recovery (mainly reverse osmosis). }\end{array}$ & - & - & $\bullet$ & - & $\bullet$ & - & - & - & - & - & (1) & - & (3) & (4) & (5) & (6) & (7) \\
\hline \multirow{11}{*}{ Energy } & $\begin{array}{l}\text { Replace the least energy-efficient equipment } \\
\text { with more energy-efficient ones. }\end{array}$ & $\bullet$ & $\bullet$ & $\bullet$ & $\bullet$ & $\bullet$ & - & - & $\bullet$ & $\bullet$ & $\bullet$ & - & (2) & (3) & - & - & - & (7) \\
\hline & $\begin{array}{l}\text { Improve equipment maintenance to enhance } \\
\text { overall energy-efficiency. }\end{array}$ & - & $\bullet$ & $\bullet$ & $\bullet$ & $\bullet$ & - & $\bullet$ & - & $\bullet$ & $\bullet$ & - & (2) & (3) & - & - & (6) & (7) \\
\hline & Control and monitor energy usage. & $\bullet$ & - & - & $\bullet$ & - & - & $\bullet$ & $\bullet$ & $\bullet$ & $\bullet$ & - & (2) & (3) & - & - & - & (7) \\
\hline & $\begin{array}{l}\text { Size motors and pumps for maximum } \\
\text { efficiency - Use frequency converters where } \\
\text { applicable. }\end{array}$ & - & - & $\bullet$ & - & $\bullet$ & - & - & $\bullet$ & $\bullet$ & $\bullet$ & (1) & (2) & - & - & - & (6) & (7) \\
\hline & $\begin{array}{l}\text { Optimise boiler and cooling system operations } \\
\text { for maximum efficiency. }\end{array}$ & - & - & $\bullet$ & - & $\bullet$ & - & $\bullet$ & $\bullet$ & $\bullet$ & $\bullet$ & (1) & (2) & (3) & - & - & (6) & (7) \\
\hline & $\begin{array}{l}\text { Improve insulation of heating and cooling } \\
\text { systems (including pipework). }\end{array}$ & • & $\bullet$ & $\bullet$ & - & • & - & • & $\bullet$ & $\bullet$ & - & - & (2) & (3) & - & - & - & (7) \\
\hline & $\begin{array}{l}\text { Recover heat wherever possible (from milk } \\
\text { fluids, water, steam, condensate, and CIP } \\
\text { solutions). }\end{array}$ & $\bullet$ & • & $\bullet$ & $\bullet$ & $\bullet$ & $\bullet$ & • & • & • & $\bullet$ & (1) & (2) & (3) & - & - & - & (7) \\
\hline & $\begin{array}{l}\text { Use alternatives source of energy (biofuel, } \\
\text { solar and wind energy). }\end{array}$ & - & - & $\bullet$ & - & - & - & • & • & - & - & - & (2) & (3) & & (5) & - & - \\
\hline & $\begin{array}{l}\text { Use non-thermal alternatives to heat } \\
\text { treatments. }\end{array}$ & $\bullet$ & - & - & - & - & $\bullet$ & - & - & - & - & - & (2) & (3) & & (5) & - & - \\
\hline & $\begin{array}{l}\text { Use membrane filtration for (pre)concentration } \\
\text { when possible. }\end{array}$ & $\bullet$ & - & • & - & - & $\bullet$ & - & • & - & - & - & (2) & - & - & - & - & (7) \\
\hline & $\begin{array}{l}\text { Adapt lighting use and maintenance - } \\
\text { possibly replace with new lighting } \\
\text { technologies. }\end{array}$ & - & - & $\bullet$ & - & - & - & - & $\bullet$ & • & - & (1) & (2) & - & - & - & (6) & (7) \\
\hline \multirow{6}{*}{$\begin{array}{c}\text { Raw } \\
\text { materials }\end{array}$} & $\begin{array}{l}\text { Optimise product formulation to improve } \\
\text { yields. }\end{array}$ & - & - & $\bullet$ & - & - & - & - & - & - & - & (1) & - & - & - & - & - & (7) \\
\hline & $\begin{array}{l}\text { Improve process control to minimise raw } \\
\text { materials and product waste. }\end{array}$ & - & - & $\bullet$ & - & $\bullet$ & - & - & - & - & $\bullet$ & (1) & - & (3) & (4) & - & - & (7) \\
\hline & $\begin{array}{l}\text { Valorise by-products (whey, permeates) to } \\
\text { minimise waste and improve value. }\end{array}$ & - & - & $\bullet$ & - & - & $\bullet$ & - & $\bullet$ & - & $\bullet$ & (1) & - & (3) & (4) & - & (6) & (7) \\
\hline & $\begin{array}{l}\text { Recover losses (cheese fines, start-up and } \\
\text { shut-down losses). }\end{array}$ & - & - & $\bullet$ & - & - & - & - & - & - & $\bullet$ & (1) & - & - & (4) & - & (6) & (7) \\
\hline & Maximise product recovery during cleaning. & - & - & $\bullet$ & - & - & - & - & - & - & $\bullet$ & (1) & - & - & (4) & - & (6) & $(7)$ \\
\hline & Use membranes to recover resources. & - & - & $\bullet$ & - & - & - & - & - & - & $\bullet$ & (1) & - & (3) & (4) & - & (6) & $(7)$ \\
\hline \multirow{6}{*}{ Waste } & $\begin{array}{l}\text { Monitor and control waste (opportunities for } \\
\text { improvement). }\end{array}$ & $\bullet$ & - & $\bullet$ & - & $\bullet$ & - & - & - & - & - & (1) & - & (3) & (4) & - & (6) & - \\
\hline & Implement on-site waste-water treatments. & $\bullet$ & - & $\bullet$ & - & $\bullet$ & - & - & - & - & $\bullet$ & (1) & - & (3) & (4) & - & (6) & $(7)$ \\
\hline & Establish a waste recycling system. & $\bullet$ & - & $\bullet$ & - & $\bullet$ & - & - & - & - & $\bullet$ & (1) & - & (3) & (4) & - & (6) & $(7)$ \\
\hline & $\begin{array}{l}\text { Optimise and control chemical dosage of } \\
\text { cleaning solutions. }\end{array}$ & - & - & $\bullet$ & - & $\bullet$ & - & - & - & - & $\bullet$ & (1) & - & (3) & - & - & (6) & (7) \\
\hline & Recover chemicals in waste-waters. & $\bullet$ & - & $\bullet$ & - & $\bullet$ & - & - & - & - & $\bullet$ & (1) & - & (3) & (4) & - & (6) & (7) \\
\hline & $\begin{array}{l}\text { Use biodegradable chemicals, find alternative } \\
\text { to chemicals (ozone, UV). }\end{array}$ & $\bullet$ & - & $\bullet$ & - & $\bullet$ & - & - & $\bullet$ & - & - & (1) & - & (3) & - & - & - & - \\
\hline
\end{tabular}

- : present

$$
\text { - : absent. }
$$

Corresponding WBCSD's eco-efficiency guidelines are indicated in last column for each recommendation.

Sources: A: Wardrop Engineering, 1997; B: UNEP-DEPA, 2000; C: UNEP, 2004; D: IDF, 2005a; E: EPA Ireland, 2008; F: Wang, 2008; G: AIG, 2010; H: Brush et al., 2011; I: NRCOEE, 2001; J: De Jong, 2013. 


\section{Measurements of Eco-efficiency}

\subsection{The First Steps: Efficiency and Intensity Assessments}

Regardless of the field, ensuring effectiveness of improvements requires the development of appropriate metrics. While the WBCSD suggested that eco-efficiency metrics should allow for quantification and comparison of how much value was generated per unit of environmental burden or unit of resource consumed (WBCSD, 2000b), most of the initial eco-efficiency metrics were based on intensity assessment. As noted by Maxime et al. (2006), the work on eco-efficiency assessment in the food and beverage manufacturing sector yielded two types of indicators: intensity indicators and eco-efficiency ratios. The former express the amounts of resources consumed per unit of production, whereas the latter may be assimilated to their reciprocal since they correspond to ratios of production value over environmental influence. The production value can be physical (volume, quantity) or financial, and the environmental influence represents the corresponding environmental burdens in terms of the quantity of resources used or pollution generated.

Table 2 summarises the main indicators recommended for eco-efficiency measurements in dairy processing in the available guides and manuals encouraging dairy processors to measure eco-efficiency. An analysis of the suggested indicators shows that the latter were structured similarly to those in Table 1. Moreover, and as explained by the UNEP (2004), most of these indicators are derived from the key performance indicators already in use by dairy processors - except for the emission-related ones, which made their first appearance.

Some limitations however must be acknowledged. Firstly, the creation by each author of very similar but different indicators and terminologies betrays an absence of consistency which could be detrimental to the dissemination and implementation of such measurements. Also, the life-cycle perspective put forward in the eco-efficiency concept does not seem to be embraced in the suggested indicators. The system boundaries to consider for the measurements are rarely mentioned, and indicators do not directly account for the environmental impacts associated with upstream and downstream actors. Furthermore, concrete environmental impacts are mostly absent apart from GHG emissions. Similarly, the notion of value appears to be relatively ambiguous. Such eco-efficiency metrics are consequently flawed: quantified improvements can potentially be carried out without economic benefits, and are at risk that improving resource intensity (a measure of the resources needed per unit of product processed) can shift burdens to other environmental dimensions.

Desires for standardised definitions and decision rules for calculating and reporting eco-efficiency indicators were expressed as from the early 2000s (OECD, 2000; WBCSD, 2000b; NRTEE, 2001). The standard on eco-efficiency assessments (ISO, 2012) developed by the International Organisation for Standardisation (ISO) aimed at meeting these expectations. 


\section{Macrothink}

Environmental Management and Sustainable Development

ISSN 2164-7682

2019, Vol. 8, No. 1

Table 2. Recommended eco-efficiency indicators according to the main guides, manuals, and articles produced before eco-efficiency assessments were normalised

\begin{tabular}{|c|c|c|c|c|c|c|c|c|c|c|c|}
\hline \multirow[b]{2}{*}{ Field } & \multirow{2}{*}{\multicolumn{3}{|c|}{ Indicator }} & \multicolumn{8}{|c|}{ Manual, guide, or article } \\
\hline & & & & $\mathrm{A}^{*}$ & B* & $\mathrm{C}$ & $\mathrm{D}^{*}$ & $\mathrm{E}$ & $\mathrm{F}^{*}$ & G & $\mathrm{H}^{*}$ \\
\hline \multirow{4}{*}{ Water } & Water intensity & Volume of water entering boundaries & Mass, Volume, or Unit of product & - & - & $\bullet$ & - & - & $\bullet$ & $\bullet$ & $\bullet$ \\
\hline & Unit water use & Volume of water use & Volume of raw milk received or processed & $\bullet$ & - & - & - & - & $\bullet$ & - & - \\
\hline & Water reuse & Volume of water reuse & Volume of water use & - & - & - & - & - & $\bullet$ & - & - \\
\hline & Water use indicator & Volume of water use & Unit of net value added & - & - & - & - & $\bullet$ & - & - & - \\
\hline \multirow{5}{*}{ Energy } & Energy intensity & Energy used within boundaries & Mass, Volume, or Unit of product & - & $\bullet$ & $\bullet$ & - & - & $\bullet$ & $\bullet$ & - \\
\hline & Fossil energy intensity & Quantity of fossil energy used & Unit of product & - & - & - & - & - & - & - & $\bullet$ \\
\hline & Electrical energy use & Total electrical energy used & Total volume of raw milk received & $\bullet$ & - & - & - & - & - & - & - \\
\hline & Thermal energy use & Total thermal energy used & Total volume of raw milk received & $\bullet$ & - & - & - & - & - & - & - \\
\hline & Energy use indicator & Total energy used & Unit of net value added & - & - & - & - & $\bullet$ & - & - & - \\
\hline \multirow{2}{*}{ Materials } & Raw material efficiency & Total mass of product & Volume of raw material consumed & - & - & - & - & - & $\bullet$ & - & - \\
\hline & Packaging intensity & Total mass of packaging used & Volume of production & - & - & - & - & - & - & $\bullet$ & - \\
\hline \multirow{5}{*}{ Waste } & Waste intensity & Mass of waste leaving boundaries & Mass, Volume, or Unit of product & - & $\bullet$ & - & - & - & $\bullet$ & - & • \\
\hline & Organic residue intensity & Total dry mass of organic residual materials & Volume of production & - & - & - & - & - & - & • & - \\
\hline & Organic waste intensity & Total dry mass of organic waste & Volume of production & - & - & - & - & - & - & $\bullet$ & - \\
\hline & Organic pollution intensity & Biochemical Oxygen Demand of Effluent (BOD) & Volume of production & - & - & - & - & - & - & $\bullet$ & - \\
\hline & Waste production indicator & Total mass of waste produced & Unit of net value added & - & - & - & - & $\bullet$ & - & - & - \\
\hline \multirow{3}{*}{ Emissions } & GHG emission intensity & Mass of GHG emissions & Volume of production & - & - & - & - & - & - & $\bullet$ & - \\
\hline & GHG intensity & Mass of GHG emissions & Quantity of energy consumed & - & - & - & - & - & - & $\bullet$ & - \\
\hline & Global warming indicator & Mass of GHG emissions & Unit of net value added & - & - & - & - & - & - & - & - \\
\hline
\end{tabular}

\subsection{The Latest Evolution: a Normalised Assessment Method}

The ISO 14045 standard sets out the principles, the requirements, and the guidelines for the eco-efficiency assessment of product systems (ISO, 2012). The standard presents eco-efficiency as an aspect of sustainability which relates the environmental performance of a product system to its product system value. The product system concept is particularly relevant to dairy processing as it refers to a collection of unit processes with elementary and product flows, performing one or more defined functions, and which models the life cycle of a product. As regards the so-called environmental performance, the standard requires it be evaluated using the LCA method. Eco-efficiency assessments consequently share many important principles with LCA such as life cycle perspective, functional unit approach, and iterative nature (ISO, 2012). In the approach suggested by the ISO standard, goal and scope (including system boundaries) are first defined and then followed by LCA and product system value assessment.

\subsection{Assessing Environmental Impacts with Life Cycle Assessment}


Often described as a decision-making tool, LCA is in fact a comprehensive approach that makes it possible to assess all the potential environmental impacts of a product, company, or service, over its entire life-cycle (Hellweg \& Mila i Canals, 2014). While there are various methods for environmental impact assessments, LCA is, according to Bellini and Janin (2011), the most recognised method at worldwide level. It is also the only method accounting for all environmental dimensions which is subject to an international standard since LCA must be carried out in accordance with the ISO 14040 and ISO 14044 standards (ISO, 2006a $\& 2006 b)$.

These standards detail the principles and framework of LCA (ISO, 2006a) and its requirements and guidelines (ISO, 2006b). The ISO 14044 standard divides LCA into four steps. During the first step, the functional unit, a reference unit used to quantify the performance of the system examined, is determined based on the chosen objectives of the study and the function of the system. An inventory, called Life Cycle Inventory (LCI), is carried out during the second step. The LCI step involves quantifying all the materials and energy flows entering (raw materials, ingredients, energy, etc.) and leaving (product, co-product(s), emissions to air and water systems, etc.) the system, such as the ones presented in figure 1. These flows are then converted into environmental impacts during the third step. This conversion requires impact analysis models (so called characterisation models and factors) in order to quantify and possibly aggregate the potential environmental impacts into categories such as Human Health, Ecosystems Quality, Climate Change, or Resources - to mention only some categories from the Impact2002+ impact analysis method (Jolliet et al., 2003). Despite their validity as climate change impact criteria, the single-criteria approaches such as fossil fuel consumption and carbon footprint fail to estimate the potential impacts within the other environmental dimensions (Jolliet et al., 2010). The fourth and final step allows for the interpretation of the LCA results in order to draw conclusions, recommendations, and decisions, in accordance with the objectives and the scope of the analysis defined during the first step (ISO, 2006b). LCA is a burdensome and possibly expensive process, but it is the method of environmental impact analysis which delivers the most comprehensive assessment (Bellini \& Janin, 2011; Leroix, 2014). However, multiple life cycle inventory databases and impact assessment methodologies are currently being developed. As they are not equivalent, the robustness of the results must be tested through sensibility analysis to avoid ill-adapted interpretations. Similarly, uncertainties related to both life cycle inventory data and impact assessment methodologies must be rigorously assessed since these evaluations are a crucial point for the credibility of LCA (Benetto, 2005).

\subsection{LCA Assessments in Dairy Processing}

Several extensive reviews and research work have already been published to date: IDF (2009), FAO (2010), Milani et al. (2011), Quantis \& Groupe Agéco (2011), Djekic et al. (2014), and Finnegan et al. (2017). Two main types of LCAs have been conducted in the dairy sector: those on milk production (Nutter et al., 2013; Van Middelaar et al., 2011), and those on dairy products such as fluid milks, cheeses, and yogurts. Comparing results within the available LCAs of the second type is challenging because of differences in system boundary definitions, functional unit choices, regional and industrial contexts, or in impact analysis methods. For 
this very reason, guides designed to standardise LCA methodology in the dairy sector have been produced by different organisms such as the International Dairy Federation (IDF, 2005b \& 2015) and the Quebec dairy processors council (Quantis \& Groupe Agéco, 2011). In the most recent review work dedicated to LCAs on dairy products (Finnegan et al., 2017), the authors focused on three environmental impact categories associated with the life-cycle of cheese (from cradle to the exit gate of the processing plant): global warming potential (GWP), acidification potential (AP), and eutrophication potential (EP). In addition to enabling evaluation of a wide range of impacts, LCA allows for contribution assessments both in terms of life-cycle stages and materials and energy flows (provided that LCI is done in sufficient detail). For instance, Finnegan et al. (2017) showed that raw milk production is the main contributor and processing the second largest contributor to GWP, AP, and EP (in different proportions however). Similarly, considering the processing life-cycle stage only, GWP is mainly driven by energy usage, AP by packaging material consumption, and EP by wastewater generation (with variations depending on volumes and treatment strategies employed).

\subsection{Determining the Associated Value}

As regards environmental impact assessment, the ISO 14045 standard leaves no choice but to use the standardised LCA methodology. In contrast, the choice of product value is still open. As long as the product value is quantifiable with reference to the same functional unit as that used for the environmental impact assessment, it can be a functional value, a monetary value, or any other type of value (ISO, 2012).

With the introduction of eco-efficiency measurements, the WBCSD suggested that net sales and net profit could both be used as product and service values (WBCSD, 2000b). Such suggestions seem, however, inconsistent with the first key aspect of eco-efficiency formulated earlier by the WBCSD (DeSimone \& Popoff, 1997). In what seems to be one of the only three available papers presenting eco-efficiency results in dairy processing (together with Lindgaard-Jørgensen et al., 2016 and Forleo et al., 2018), Van Middelaar et al. (2011) mentioned that economic performance in such assessments can be measured as gross value added, production costs, or income. They also suggested that profit be used as such a value, in order to gain insight into the economic position of chain actors and their ability to invest in improvements. In contrast with net sales, gross value added, and production costs, net profit has the significant advantage of providing clear profitability data. Since it considers all operating expenditures (both direct and indirect) and total revenues, opting for net profit ensures that breakdowns of all incoming and outgoing economic flows are included in the product value calculation at the processing stage. Moreover, net profit computation can be used to estimate minimum production levels from which processes begin to be economically profitable (Desforges \& El Hjaji, 2012). Incidentally, Peters (2005) took advantage of this property in a study on the economical reverberations of production scales and whey treatment strategies in cheese production. For instance, net profit calculations made it possible for Peters to estimate, under the study conditions, that when liquid whey sells at 0.32 US\$ per $\mathrm{kg}$, the sales price of milk protein concentrates (34\% proteins) must be higher than 1.15 US\$ per $\mathrm{kg}$ to avoid negative cash flows. Similarly, if milk protein isolates (90\% proteins) sell at 
5.00US\$ and whey powder at 0.70US\$ per $\mathrm{kg}$, opting for the latter will generate higher profits.

When it comes to dealing with economics and life-cycle perspective, Life Cycle Costing (LCC) methodologies might come in handy. This methodology allows for a complete assessment of total costs associated with the life-cycle of a product (Hunkeler et al., 2008). It accounts for acquisition costs, operating and possible maintenance expenses, and the potential end-of-life related costs (IFDD, 2016). Unlike LCA, LCC it is not a standardised methodology. However, it shares several principles with LCA such as boundaries definition (cradle-to-grave, cradle-to-gate, gate-to-gate) and expression of results in relation to a functional unit. Several types of LCC exist (Hunkeler et al., 2008). Conventional LCC corresponds to the costing practices currently enforced in manufacturing companies: it only accounts for costs related to the processing stage of the product life-cycle, and the functional unit is the product. It relies on calculations of purchasing and production expenses related to a single actor in the value chain, such as the dairy processor for instance. Environmental LCC is done in conjunction with an LCA, with the same boundaries and functional unit (Hunkeler et al., 2008). It therefore accounts for both economic costs and environmental impacts through multiple life-cycle stages. With suitable boundaries, end-of-life treatments, for example, can be considered in environmental LCC while they are usually absent from conventional LCC. With LCI involving listing all materials and energy flows entering and exiting the system, it can effectively serve as a basis for LCC and thus reduce the related workload, which is a significant asset. Depending on boundaries definition (from one to all the actors of the product life-cycle), environmental LCC can either help in linking the financial profitability and environmental impacts of the product from a single actor point of view, or concomitantly assess the economic and environmental dimensions of the product from a value chain perspective. Although the latter option might seem particularly appropriate for an entity that would require such point of view (such as a regulatory body), it is likely that in a decision-making context, and more specifically because profits are not shared equally among the value chain actors, dairy processors would be more interested in the former. In that case, it seems reasonable to assume that an environmental LCC would be reduced to a conventional LCC coupled to an LCA. Such approach makes it possible to concurrently assess economical value and environmental impacts, and to calculate the net profit and profitability thresholds, two useful indicators for decision makers in manufacturing industries (Desforges \& El Hjaji, 2012).

One challenge in choosing the value with which the system is to be assessed concerns the selection of a metric that can add positively to all the players of the product life-cycle. Indeed, the net profit generated by the dairy processor does not guarantee an improved value for the downstream actors (distributors, consumers, waste processors). Assuming that the actors along the supply chain do not sell at a loss, all costs and profits of the dairy processors, dairy farmers, hauliers, energy, water, and equipment suppliers are taken into account in the dairy processor net profit. However, the issue lies in the definition of system boundaries, since a system whose boundaries stop at the exit gate of the dairy processor would account for all costs and profits of the truncated life-cycle. Also, as shown by Lindgaard-Jørgensen et al. 
(2016), boundaries can be extended to include downstream actors, and the associated value can be an addition of all the actors' net profit. The question then arises as to whether or not it leads to multiple counting of the same profits, thus artificially increasing the value added. Either way, it should be noted that none of these solutions guarantee a fair economic fallout among the stakeholders. In view of this challenge, a number of studies examined the concept of value chain approach (namely all the products and actors either directly or indirectly involved in the serving the market) in the decision-making process in order to achieve economic viability, environmental preservation, consumer satisfaction, and broader contributions to the society (Mitchell et al., 2009; Khoi, 2013; Nyaoga \& Magutu, 2016). As in the case for LCA, the system boundaries and its associated value must be chosen carefully to quantify the value in a comprehensive manner and to make sure the selected metric assessing the value is in line with the objectives of the eco-efficiency assessment.

\subsection{Eco-efficiency Indicators}

In order to quantify eco-efficiency, the standard organisation endorsed the use of eco-efficiency ratios as earlier suggested by the WBCSD (2000b). These ratios became Eco-Efficiency Indicators (EEI) and are designed to express generated value per unit of environmental influence. They are thus calculated by dividing the product value by its associated environmental impact (both expressed with respect to the same functional unit). As several impact analysis methods and environmental impact categories exist, multiple EEIs are usually calculated. For instance, in one of the only two available eco-efficiency assessments in dairy processing based on the ISO 14045 standard (with Forleo et al., 2018), Lindgaard-Jørgensen et al. (2016) used the CML2001 impact assessment method (Guinée, 2002) to evaluate the environmental performance over eight impact categories. Eight EEIs were thus calculated, one for each environmental dimension: EEI-1 expressed in $€ / \mathrm{kg} \mathrm{CO} 2 \mathrm{eq}$. (climate change), EEI-5 in $€ / \mathrm{kg}$ SO2- eq. (acidification), and EEI-8 in $€ / \mathrm{kg} \mathrm{C} 2 \mathrm{H} 4$ eq. (photochemical ozone formation), to mention but a few. While several impact assessment methods offer different aggregation schemes of a relatively large numbers of impact indicators into a smaller number - Eco-Indicator 99 (DMHSPE, 2000), Impact 2002+ (Jolliet et al., 2003) - this practice is likely to hide potentially important information about the eco-efficiency performance (WBCSD, 2000b). In such a case, interpretation of eco-efficiency results must be done cautiously in order to identify any potential trade-offs between aggregated environmental indicators. In the form suggested by the ISO, an increase in the value of an EEI reflects a positive performance improvement. While this can be useful when comparing eco-efficiency assessments results, there is, however, a danger that the value of an EEI increases without a real improvement in the environmental parameter, or even worse, with a degradation of the associated environmental impact. With a sufficient increase in value, EEI values can indeed increase despite expansions of the environmental impacts. For that very reason, the ISO standard specifies that, in such case, improved eco-efficiency can only be claimed if the assessment results show an equal or better environmental performance (ISO, 2012).

The final and ultimate step of eco-efficiency assessments according to the ISO standard is result interpretation. Even if it might be assumed that the use of EEIs simplify this last stage, 
several difficulties could still subsist. Firstly, results are evidently only valid in the scope defined at the first step. Eco-efficiency improvements within narrow boundaries could therefore hide the shift of impacts towards other actors of the product life-cycle. Similarly, EEIs based on aggregated environmental impacts must be examined in depth to ensure that potential improvements are not the result of shiftings of impacts between several environmental dimensions. Also, while some environmental impact reductions can often be correlated with enhanced economic values, those with longer term and more global effects tend to increase with economic value improvements (Raymond, 2004). Furthermore, besides the comparison of EEIs, analysis of the contributions of the materials and energy flows in both product value and environmental impacts could allow for hot-spot identifications and thus potential improvement opportunities. Finally, as EEIs are based on measurements, calculations, and impact analysis models, a degree of uncertainty is associated with each result. Uncertainty assessment is therefore suggested by the ISO standard in order to fully appreciate the limitations of the results.

Figure 3 underlines key milestones that have contributed to the progress in each dimension of the concept and have contributed to the evolution of the eco-efficiency assessment up to a standardised method. Following concept description and guidelines for eco-efficiency improvements, eco-efficiency assessments were introduced, and then supplemented with the rigorous environmental impact assessments it was lacking to become a promising standard. In the light of the advances of the last thirty years, it seems reasonable to assume industrialists are now being given the required tools to delink economic growth from resources consumptions and environment degradation, with the ISO 14045 standard bringing the required rigorousness and clarifications to the measurement of eco-efficiency. Nevertheless, the necessary data collection can still be very challenging and burdensome and additional tools could be required.

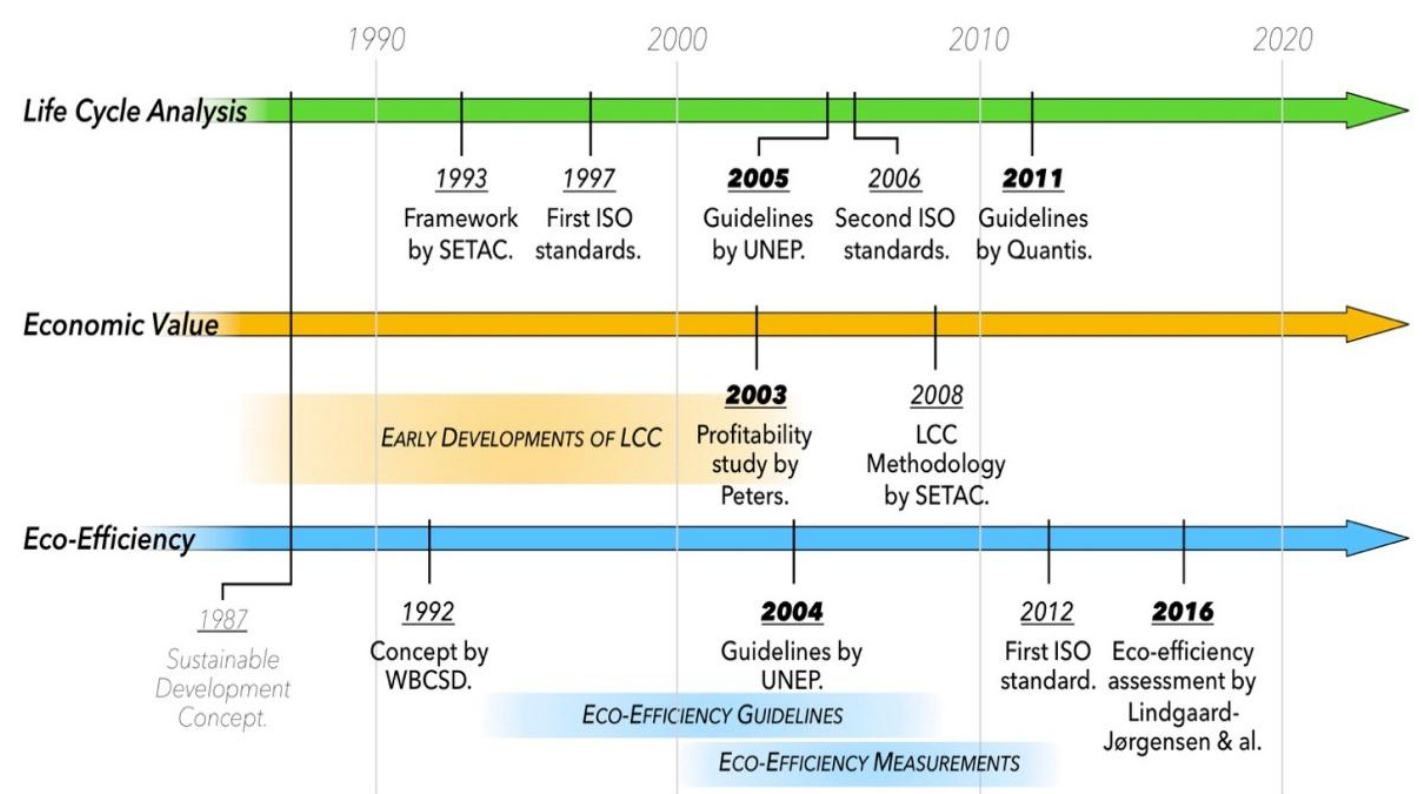

Figure 3. Historical timeline of the main advances related to eco-efficiency assessments. Dates in bold indicate a dairy processing related event 


\section{Process Simulation as Support for Eco-efficiency Assessments}

Data collection and LCA are two critical aspects of eco-efficiency assessments. On the one hand, tools such as EcodEX (Schenker et al., 2014), eVerdEE or CCaLC (Arzoumanidis, 2017) can certainly ease the LCA step of eco-efficiency assessments in the agri-food sector. However, carrying out inventories on material and energy flows are still required and these tools are not specific to the dairy processing activity. On the other hand, it seems that improved process simulation softwares could provide a valuable help for eco-efficiency assessment in dairy processing.

Process simulation enables the analysis of a process or a system by means of mathematical models (Bimbenet et al., 2007). In the fuel, chemical, and pharmaceutical industries, process simulators are omnipresent. These tools are not only used to rapidly and cost-effectively design more sustainable processes, but also to assess and optimise existing processes (Joulia, 2008). Process simulators are computer programs which, over the whole process, link modules representing unit processes to mass and energy balances (Tomasula et al., 2013). Process simulation is what Bimbenet et al. (2007) call a "tool for the exploration of possibilities ». It indeed enables mass and energy flow predictions of any modelled process and allows for rapid comparisons between different scenarios in a decision-making process. Process simulators have two main objectives: mass and energy balance for each unit process, and calculation of all the fluid flow parameters such as flow, composition, temperature, and pressure. Some of the softwares currently available also offer estimations of investment and operation costs, environmental impact assessments, and optimisation of the process parameters. According to Joulia (2008), the most used commercial process simulators are Aspen Plus ${ }^{\mathrm{TM}}$, Chemcad ${ }^{\mathrm{TM}}$, Aspen HYSYS ${ }^{\mathrm{TM}}$, SimSci Pro/II ${ }^{\mathrm{TM}}$, and ProSimPlus ${ }^{\mathrm{TM}}$. Because the vast majority of these softwares are intended for chemical and petrochemical industries, they do not include the models required for dairy processing use. Nevertheless, two studies on energy consumption, GHG emissions, and the economic aspect of fluid milk production were conducted in recent years (Tomasula et al., 2013 \& 2014) with the help of Super Pro Designer $^{\mathrm{TM}}$, a process simulation software, dedicated to the industries in the biotechnology, pharmacology, chemical, mineral processing, and consumer goods fields (Intelligen, 2014).

The software used by Tomasula et al. (2013 \& 2014) includes models for 140 unit processes, including membrane filtration. It allows for the setting of each fluid flow and process unit (in terms of temperature, pressure, and yield) and also includes a tool for calculations of waste-waters and volatile compounds productions. In regard to economical assessment, values must be provided by users. Because the software does not distinguish between the different energy sources, the authors of the studies had to develop a side-program capable of extracting energy consumptions from the software before converting them into GHG emissions using conversion factors from literature. In their 2013 study, Tomasula et al. used process simulation to compare GHG emissions of three different sizes of plants producing fluid milk (40, 114, and 227 million litres per an). They concluded that, according to their models, the differences in volumes processed do not impact the carbon footprint results. The GHG emissions calculated were incidentally very close $( \pm 5 \%)$ to those in the results of published LCAs. In their 2014 study, they used the same method to compare several fluid 
milk pasteurisation technologies and concluded that the process responsible for the least GHG emissions was the least costly and also resulted in the shortest product lifespan (Tomasula et al., 2014). Although eco-efficiency assessment of the modelled processes was not the goal in these studies, it is fairly obvious from these examples that process simulation could help dairy processors to look for improvements, whether it is regarding operating mode modifications or implementation of new processes, and to observe potential impacts on energy consumption and costs without having to conduct costly operations.

\section{Conclusion}

Specifically dedicated to the business community, the eco-efficiency concept was created with the aim of promoting a healthy competition in the world of industry, by decoupling economic growth from the use of resources and the generation of pollutions. The concept in itself has not evolved since the 1997 and 2005 comprehensive definitions by the WBCSD. However, the ways eco-efficiency has been used and implemented since its introduction have changed over the years. Early on, many organisms issued recommendations dedicated to dairy processors in order to improve their eco-efficiency. Proposals of Indicators then followed. Without restrictive regulations and comprehensive methodologies integrating the life-cycle perspective in eco-efficiency assessments, the potential improvements in the eco-efficiency of dairy processing remained difficult to quantify thoroughly and accurately. To address these issues, the International Standard Organisation issued a standard for eco-efficiency assessments. With the ISO 14045 standard, a complete methodology imposing LCA as part of eco-efficiency assessment has emerged. While this standard brought the required rigorousness and clarifications to the measurement of eco-efficiency, several challenges remain related to the required inventories of materials and energy flows, the needs for specific competences to conduct in-depth LCAs, and the selection of a value that can add positively to all the players of the product life-cycle. While the dairy processing sector seems to have demonstrated a keen interest in the eco-efficiency concept since the beginning (dedicated guidelines and metrics), it did not embrace a sector wide implementation of the standardised eco-efficiency methodology. While results of only a few comparative eco-efficiency assessments carried out in the dairy processing sector are available, literature on effective eco-efficiency improvements obtained in dairy processing is virtually non-existent. This inaccessibility risks undermining efforts of dairy processors to overcome the remaining challenges currently associated with eco-efficiency assessment, thereby reducing opportunities for dairy processes to generate more value with less environmental impacts. However, the advent of process simulation tools could potentially help in facilitating the implementation by easing the inventory of materials and energy flows in the dairy processing sector. Then, perhaps, eco-efficiency assessments in dairy processing will enter the second wave of its development.

\section{Acknowledgement}

This work was supported by the Natural Sciences and Engineering Research Council of Canada and Novalait Inc. 


\section{References}

AIG. (2010). Saving energy in the dairy processing industry. Australian Industry Group's Energy and Sustainable Business Publication.

Arzoumanidis, I., Salomone, R., Petti, L., Mondello, G., \& Raggi, A. (2017). Is there a simplified LCA tool suitable for the agri-food industry? An assessment of selected tools. Journal of Cleaner Production, 149, 406-425. http://dx.doi.org/10.1016/j.jclepro.2017.02.059

BCSD. (1992). Changing Course: A Global Business Perspective on Development and the Environment. The MIT Press. Cambridge. Massachusetts.

BCSD. (1993). Getting Eco-Efficient. Report of the Business Council for Sustainable Development-First Antwerp Eco-Efficiency Workshop November 1993. Business Council for Sustainable Development Publication.

Bellini, B., \& Janin, M. (2011). Éco-conception: état de l'art des outils disponibles. Éco-Conception. Techniques de l'Ingénieur Ref. G6010.

Benetto, E. (2005). Analyse du cycle de vie. Incertitudes des évaluations des impacts. Éco-Conception. Techniques de l'Ingénieur Ref. G5620.

Bimbenet, J-J., Duquenoy, A., \& Trystram, G. (2007). Génie des procédés alimentaires des bases aux applications. (2nd ed.). Dunod. ISBN: 978-2-100-50470-1.

Brush, A., Masanet, E., \& Worrell, E. (2011). Energy Efficiency Improvement and Cost Saving Opportunities for the Dairy Processing Industry. An ENERGY STAR ${ }^{\circ}$ Guide for Energy and Plant Managers. Lawrence Berkeley National Laboratory Publication.

CDC. (2017). Dairy Ingredient Profiles. Canadian Dairy Commission Publication.

De Boer, R. (2014). From Milk By-Products to Milk Ingredients Upgrading the Cycle. Wiley-Blackwell Publication. ISBN: 978-0-470-67222-8.

De Jong, P. (2013). Sustainable Dairy Production. John Wiley \& Sons, Ltd. Publication. ISBN: 978-0-470-65584-9.

Desforges, P., \& El Hjaji, Y. (2012). Coût de revient et prise de décision. Communication Directorate of Quebec Ministry of Economic Development, Innovation, and Exportation. Quebec Government Publication.

DeSimone, L.D., Popoff, F. World Business Council for Sustainable Development. (1997). Eco-efficiency: The Business Link to Sustainable Development. The MIT Press. Cambridge. Massachusetts.

Djekic, I., Miocinovic, J., Tomasevic, I., Smigic, N., \& Tomic, N. (2014). Environmental life-cycle assessment of various dairy products. Journal of Cleaner Production, 68, 64-72. http://dx.doi.org/10.1016/j.jclepro.2013.12.054

DMHSPE. (2000). Eco-Indicator 99 Manual for Designers. Dutch Ministry of Housing. Spatial Planning and the Environment Publication. 
EPA Ireland. (2008). BAT Guidance Note on Best Available Techniques for the Dairy Processing Sector. Environmental Protection Agency. Ireland.

FAO. (2010). Greenhouse Gas Emissions from the Dairy Sector-A Life Cycle Assessment. Food and Agriculture Organisation of the United Nations Publication.

FAO. (2016). The Global Dairy Sector: Facts. Food and Agriculture Organisation of the United Nations Publication.

FAOSTAT. (2014). Food and Agriculture Data. Statistics Division. Food and Agriculture Organisation of the United Nations Publication.

Finnegan, W., Mingjia, Y., Holden, N. M., \& Goggins, J. (2017). A review of environmental life cycle assessment studies examining cheese production. Int. J. Life Cycle Assess. http://dx.doi.org/10.1007/s11367-017-1407-7.

Forleo, M.B., Palmieri, N., \& Salimei, E. (2018). The eco-efficiency of the dairy cheese chain: an Italian case study. Italian J. Food Sci., 30, 362-380. http://dx.doi.org/10.14674/IJFS-1077.

Gendron, C., \& Gagnon, C. (2011). Développement durable et économie sociale : convergences et articulations. Les cahiers de la CRSDD. Collection recherche No 02-2011. Bibliothèque et Archives nationales du Québec.

Guinée, J. B., Gorrée, M., Heijungs, R., Huppes, G., Kleijn, R., De Koning, A., ... Huijbregts, M. A. J. (2002). Handbook on life cycle assessment. Operational guide to the ISO standards. I: LCA in perspective. IIa: Guide. IIb: Operational annex. III: Scientific background. Kluwer Academic Publishers. Dordrecht. ISBN 1-4020-0228-9.

Hellweg, S., \& Mila i Canals, L. (2014). Emerging approaches, challenges and opportunities in life cycle assessment. Science., 344, 1109-1113.

http://dx.doi.org/10.1126/science.1248361.

Hunkeler, D., Lichtenvort, K., \& Rebitzer, G. (2008). Environmental Life Cycle Costing. the Society of Environmental Toxicology And Chemistry. CRC Press Publication. ISBN: 978-1-420-05470-5.

IDF. (2005a). Energy use in Dairy Processing. Bulletin of the International Dairy Federation No. 401. International Dairy Federation Publication.

IDF. (2005b). Guide on Life Cycle Assessment towards Sustainability in the Dairy Chain. Bulletin of the International Dairy Federation No. 398. International Dairy Federation Publication.

IDF. (2009). Environmental / Ecological Impact of the Dairy Sector: Literature review on dairy products for an inventory of key issues List of environmental initiatives and influences on the dairy sector. Bulletin of the International Dairy Federation No. 436. International Dairy Federation Publication.

IDF. (2015). A common carbon footprint approach for the dairy sector-The IDF guide to standard life cycle assessment methodology. Bulletin of the International Dairy Federation 
No. 479. International Dairy Federation Publication.

IFDD. (2016). Coût du cycle de vie. Institut Fédéral pour le Développement Durable-Belgian Federal Institute for Sustainable Development Publication.

Intelligen. (2014). Company Information. [Online] Available:

http://www.intelligen.com/compinfo.html (February 12, 2018).

ISO. (2006a). ISO 14040: Environmental management-Life cycle assessment-Principles and framework. ( $2^{\text {nd }}$ ed.). International Standard Organisation Publication.

ISO. (2006b). ISO 14044: Environmental management-Life cycle assessment-Requirements and guidelines. $\left(1^{\text {st }}\right.$ ed.). International Standard Organisation Publication.

ISO. (2012). ISO 14045: Environmental management-Eco-efficiency assessment of product systems-Principles, requirements and guidelines. International Standard Organisation Publication.

Jolliet, O., Margni, M., Charles, R., Humbert, S., Payet, J., Rebitzer, G., \& Rosenbaum, R. (2003). IMPACT 2002+: A new life cycle impact assessment methodology. Int. J. Life Cycle Assess, 8, 324-330. http://dx.doi.org/10.1007/BF02978505.

Jolliet, O., Saadé, M., Crettaz, P., \& Shaked, S. (2010). Analyse du cycle de vie. Comprendre et réaliser un écobilan. ( $2^{\text {nd }}$ ed.). Presses Polytechniques et Universitaires Romandes. ISBN: 978-2-880-74886-9.

Joulia, X. (2008). Simulateurs de procédés. Industrialisation des procédés : défis et nouvelles approches. Techniques de l'Ingénieur Ref J1022.

Khoi, N. V. (2013). Wicked problems: a value chain approach from Vietnam's dairy product. Springer Plus., 2,161. http://dx.doi.org/10.1186/2193-1801-2-161.

Leroix, Y. (2014). Éco-concevoir, les outils et méthodes. Pratique de la conception industrielle. Techniques de l'Ingénieur Ref. 0276.

Lindgaard-Jørgensen, P., Kristensen, G. H., \& Andersen, M. (2016). Technology Options in a Dairy Plant: Assessing Whole-System Eco-Efficiency. Environmental Management and Sustainable Development, 5, 1-16. http://dx.doi.org/10.5296/emsd.v5i1.8655.

Maxime, D., Marcotte, M., \& Arcand, Y. (2006). Development of eco-efficiency indicators for the Canadian food and beverage industry. Journal of Cleaner Production, 14, 636-648. http://dx.doi.org/10.1016/j.jclepro.2005.07.015.

Milani, F. X., Nutter, D., \& Thoma, G. (2011). Environmental impacts of dairy processing and products: A review. J. Dairy Sci., 94, 4243-4254.

http://dx.doi.org/10.3168/jds.2010-3955.

Mitchell, J., Keane, J., \& Coles, C. (2009). Trading Up: How a Value Chain Approach Can Benefit the Rural Poor. Overseas Development Institute. London. UK.

NRCOEE. (2001). Energy Performance Indicator Report: Fluid Milk Plants. Prepared for the 
National Dairy Council of Canada. Natural Resources Canada's Office of Energy Efficiency Publication.

NRTEE. (2001). Calculating Eco-Efficiency Indicators: A Workbook for Industry. National Round Table on the Environment and the Economy Publication.

Nutter, D. W., Kim, D. S., Ulrich, R., \& Thoma, G. (2013). Greenhouse gas emission analysis for USA fluid milk processing plants: Processing, packaging, and distribution. Int. Dairy J., 31, S57-S64. http://dx.doi.org/10.1016/j.idairyj.2012.09.011.

Nyaoga, R. B., \& Magutu, P. B. (2016). Constraints management and value chain performance for sustainable development. Management Sci. Letters, 6, 427-442.

http://dx.doi.org/10.5267/j.msl.2016.4.002.

OECD. (1998). Eco-efficiency. Organisation for Economic Co-operation and Development Publication.

OECD. (2000). STI REVIEW-Special Issue on Sustainable Development No. 25. Organisation for Economic Co-operation and Development Publication.

Olivier, J. G. J., Schure, K. M., \& Peters, J. A. H. W. (2017). Trends in global CO2 and total greenhouse gas emissions-Summary of the 2017 report. PBL Netherlands Environmental Assessment Agency. The Hague.

Oxford English Dictionary. (2012). Oxford University Press.

Peters, R. H. (2005). Economic aspects of cheese making as influenced by whey processing options. Int. Dairy J., 15, 537-545. http://dx.doi.org/10.1016/j.idairyj.2004.11.009.

Quantis \& Groupe Agéco. (2011). Lignes directrices pour la réalisation d'analyses du cycle de vie environnementale et sociale-Secteur des produits laitiers au Québec. Quantis \& Groupe Agéco Publication.

Raymond, L. (2004). Economic Growth as Environmental Policy? Reconsidering the Environmental Kuznets Curve. J. Publ. Pol., 24, 327-348.

http://dx.doi.org/10.1017/S0143814X04000145.

Schenker, U., Espinoza-Orias, N., \& Popovic, D. (2014). EcodEX: A simplified ecodesign tool to improve the environmental performance of product development in the food industry. 9th International Conference LCA of Food San Francisco. USA 8-10 October 2014.

Schuck, P., Dolivet, A., Méjean, S., Tanguy, G., \& Garreau, D. (2016). Technological breakthrough and innovation in the production of whey powders, with 30-40\% reduction in energy costs. Proceedings of the 5th International Congress on Green Process Engineering. Engineering Conferences International ECI Digital Archives.

Tetra Pak. (2015). Dairy Processing Handbook. ( $3^{\text {rd }}$ ed.). Tetra Pak Processing Systems AB Publication.

Thoma, G., Popp, J., Nutter, D., Shonnard, D., Ulrich, R., Matlock, M., ... Adom, F. (2013). 
Greenhouse gas emissions from milk production and consumption in the United States: A cradle-to-grave life cycle assessment circa 2008. Int. Dairy J., 31, S3-S14.

http://dx.doi.org/10.1016/j.idairyj.2012.08.013.

Tomasula, P. M., Datta, N., Yee, W. C. F., McAloon, A. J., Nutter, D. W., Sampedro, F., \& Bonnaillie, L. M. (2014). Computer simulation of energy use, greenhouse gas emissions, and costs for alternative methods of processing fluid milk. J. Dairy Sci., 97, 4594-4611. http://dx.doi.org/10.3168/jds.2013-7546.

Tomasula, P. M., Yee, W. C. F., McAloon, A. J., Nutter, D. W., \& Bonnaillie, L. M. (2013). Computer simulation of energy use, greenhouse gas emissions, and process economics of the fluid milk process. J. Dairy Sci., 96, 3350-3368. http://dx.doi.org/10.3168/jds.2012-6215.

TSC. (2013). Key Performance Indicator. Category: Milk. The Sustainability Consortium Publication.

UNCTAD. (2004). A Manual for the Preparers and Users of Eco-Efficiency Indicators. United Nations Conference on Trade and Development. United Nations Publication.

UNEP-DEPA. (2000). Cleaner Production Assessment in Dairy Processing. United Nations Environment Programme and Danish Environmental Protection Agency Joint Publication.

UNEP-WBCSD. (1998). Cleaner Production and Eco-efficiency, complementary approaches to sustainable development. United Nations Environment Programme and World Business Council for Sustainable Development Joint Publication.

UNEP. (2004). Eco-efficiency for the Dairy Processing Industry. The UNEP Working Group for Cleaner Production in the Food Industry. United Nations Environment Programme Publication.

UNESCAP. (2009). Eco-efficiency Indicators: Measuring Resource-use Efficiency and the Impact of Economic Activities on the Environment. United Nations Economic and Social Commission for Asia and the Pacific. United Nations Publication.

UNWCED. (1987). Our Common Future. United Nations World Commission on Environment and Development Publication.

USDA. (2016). National Nutrient Database for Standard Reference Release 28. United States Department of Agriculture. Agricultural Research Service Publication.

Van Middelaar, C. E., Berentsen, P. B. M., Dolman, M. A., \& de Boer, I. J. M. (2011). Eco-efficiency in the production chain of Dutch semi-hard cheese. Livestock Sci., 139, 91-99. http://dx.doi.org/10.1016/j.livsci.2011.03.013.

Walstra, P., Wouters, J. T. M., \& Geurts, T. J. (2006). Dairy Science and Technology. (2 ${ }^{\text {nd }}$ ed.). Taylor \& Francis Group. LLC. ISBN: 978-0-824-72763-5.

Wang, L. (2008). Energy Conservation in Dairy Processing Facilities. Energy Efficiency and Management in Food Processing Facilities. CRC Press. Taylor \& Francis Group. 


\section{Macrothink \\ Environmental Management and Sustainable Development \\ ISSN 2164-7682 2019, Vol. 8, No. 1}

Wardrop Engineering. (1997). Guide to Energy Efficiency Opportunities in the Dairy Processing Industry. Wardrop Engineering Inc. for the National Dairy Council of Canada.

WBCSD. (2000a). Eco-efficiency: creating more value with less impact. World Business Council for Sustainable Development Publication.

WBCSD. (2000b). Measuring eco-efficiency-a guide to reporting company performance. World Business Council for Sustainable Development Publication.

WBCSD. (2005). Eco-efficiency-Learning Module. World Business Council for Sustainable Development Publication.

World Resources Institute. (2016). Shifting diets for a sustainable food future. Working Report. World Resources Institute Publication

\section{Copyright Disclaimer}

Copyright for this article is retained by the authors, with first publication rights granted to the journal.

This is an open-access article distributed under the terms and conditions of the Creative Commons Attribution license (http://creativecommons.org/licenses/by/3.0/). 